\title{
Progressive eutrophication behind the world-largest super floating macroalgal blooms in the Yellow Sea
}

\section{Q. Xing ${ }^{1}$, M. Gao ${ }^{1}$, X. Gao ${ }^{1}$, L. Tosi ${ }^{2}$, F. G. Schmitt ${ }^{3}$, Y. Zhang ${ }^{4}$, P. Shi ${ }^{1}$, J. Wei ${ }^{5}$,} and Y. Luo ${ }^{1}$

${ }^{1}$ Yantai Institute of Coastal Zone Research, Chinese Academy of Sciences, No. 17 Chunhui Road, Laishan District, Yantai 264003, China

${ }^{2}$ Institute of Marine Sciences, National Research Council, Arsenale - Tesa 104, Castello 2737/F, 30122 Venezia, Italy

${ }^{3}$ Laboratory of Oceanology and Geosciences, Centre National de la Recherche Scientifique, 28 Av. Foch, 62930 Wimereux, France

${ }^{4}$ The Chinese University of Hong Kong, Shatin, NT, Hong Kong

${ }^{5}$ Department of Atmospheric and Oceanic Sciences, Peking University, No. 5 Yiheyuan Road, Haidian District, Beijing 100871, China

Received: 19 March 2014 - Accepted: 21 April 2014 - Published: 16 May 2014

Correspondence to: Q. Xing (qgxing@yic.ac.cn)

Published by Copernicus Publications on behalf of the European Geosciences Union.
Eutrophication

behind the

world-largest floating

macroalgal blooms

Q. Xing

\section{Title Page}

Abstract

Introduction

Conclusions

References

Tables

Figures

14

4

Back

Full Screen / Esc

Printer-friendly Version

Interactive Discussion 


\section{Abstract}

World-largest super floating macroalgal blooms of Ulva prolifera have lasted 7 years by now in every summer in the Yellow Sea, the outer part of a semi-enclosed coastal sea. Evaluation of the inter-annual variability in the trophic status is one of fundamen5 tal tasks for prediction and management of the blooms. We show the new findings of a progressive eutrophication in the large Yellow Sea basin behind the super floating macroalgal blooms. The inter-annual variability in human-induced nutrient pollution from 2001 to 2012 was assessed by a nutrient pollution index weighted by area (AWCPI-NP), and a significant increase in the trophic status was found in the macroalgal bloom (MAB) phase (2007-2012): the average AWCPI-NP was higher than that in the pre-MAB phase (2001-2006) by about $45 \%$; meanwhile, in the Jiangsu Shoal, origin place of the drifting macroaglae, the annual in-situ nutrient concentrations increased rapidly from 2000 to 2011 . Chlorophyll a concentration (Chl a), an indicator of eutrophication, increased by about $15 \%$ in the bloom region from the pre-MAB to MAB phase. This progressive eutrophication might lead to the non-linear outburst in the growth of macroalgae, i.e., green tides, in the Yellow Sea since 2007.

\section{Introduction}

Satellite image records revealed that large scale of macroalgae blooms (MAB) started from 2007 in the Yellow Sea (Hu et al., 2010; Xing et al., 2011a; Keesing et al., 2011); these floating macroalgal blooms have seriously impacted the Yellow Sea by covering hundreds of square kilometers of ocean surface in every summer (Liu et al., 2009; Xing et al., 2011a; SOA, 2013). In the early May, i.e., at the early stages of bloom, the patches of floating algae Ulva prolifera from the turbid waters of Jiangsu Shoal usually drift southward along with the Jiangsu Coastal Current, and enter the East China Sea; as the Northeast Asia monsoon becomes stronger, most of the floating macroalgae
BGD

$11,7029-7054,2014$

Eutrophication

behind the

world-largest floating

macroalgal blooms

Q. Xing

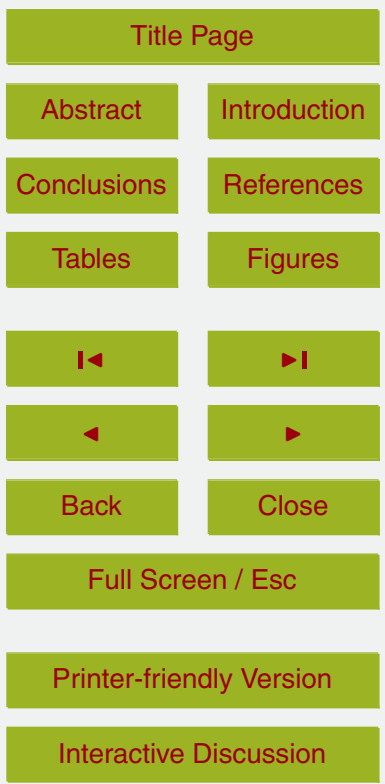


drift northwardly and reach the southern coast of Shandong peninsula in June and July; and they disappear in August (Fig. 1) (Xing et al., 2011a).

The super macroalgal blooms brought adverse impacts on local coastal tourism, marine transportation, fisheries, and the aquatic systems; the blooms aroused a global 5 concern on coastal marine environment (Sun et al., 2008; LOICZ, 2008; Hu and He, 2008; Smetacek and Zingone, 2013), especially on eutrophication. The dynamics of phytoplankton is usually controlled by nutrients in aquatic ecosystem (Tilman et al., 1982; Hecky et al., 1988; Egge and Aksnes, 1992; Gao and Song, 2005); similarly for macroalgae, growth of Ulva ssp. and Enteromorpha spp. was highly related to the en10 richment of nutrient (especially the nitrogen) as shown by experimental and numerical studies (Menesguen et al., 2006).

Eutrophication, a process of nutrient enrichment of water (Lund, 1967; Ferreira et al., 2011), is a significant problem for coastal marine system (Turner and Rabalais, 1994; Cai et al., 2011), and nitrogen and phosphorus are recognized as the major 15 pollutants causing eutrophication (García-Pintado et al., 2007; Kauffman et al., 2010). In China, Coastal water quality levels (WQLs) and their spatial distribution are annually presented in Marine Environmental Quality Bulletin, and the WQLs have been dominated by the nutrient pollution, i.e. the total inorganic nitrogen (TIN-N) and the active phosphorus $\left(\mathrm{PO}_{4}-\mathrm{P}\right)(\mathrm{SOA}, 2010,2011,2013)$. So, the eutrophication may be reason of macroalgal blooms in the China coastal waters.

However, to our knowledge, there is neither long-term data nor effective approaches for evaluation of macroalgae related nutrient enrichment in the entire semi-enclosed region of the Large Yellow Sea basin which includes the Yellow Sea and the Bohai Sea. Chlorophyll a $(\mathrm{Chl} \mathrm{a),} \mathrm{a} \mathrm{pigment} \mathrm{in} \mathrm{phytoplankton,} \mathrm{is} \mathrm{extensively} \mathrm{used} \mathrm{as} \mathrm{an} \mathrm{indicator}$ in eutrophication assessment (Carlson, 1977; Ferreira et al., 2011). However, the longterm records of in situ $\mathrm{Chl}$ a are scarce because it is not a compulsory parameter in the marine environmental monitoring system in China (Qu et al., 2006). Alternatively, satellite remote sensing data in archive has the potential in providing historical records of Chl a, and can be used for long-term assessment (Bot and Colijin, 1996).

BGD

11, 7029-7054, 2014

Eutrophication

behind the

world-largest floating

macroalgal blooms

Q. Xing

Title Page

Abstract

Introduction

Conclusions

Tables

References

Figures

14

4

Back

Full Screen / Esc

Printer-friendly Version

Interactive Discussion $\rightarrow 1$

Close 
In order to understand the causes of macroalgal blooms in the Yellow Sea, it is essential to know the status and trend of nutrient enrichment before and after the largescale macroalgal blooms. In this paper, we use Chl a to analyze the change and trend of eutrophication as well as an index combining the area of nutrient-polluted marine 5 waters and their corresponding level to evaluate the entire regional trophic status of coastal waters, and explore the process of eutrophication behind the super macroalgal blooms.

\section{Data and methods}

\subsection{Studied area and field work}

10 The Yellow Sea (Fig. 1) is a semi-enclosed coastal sea with an area of $380000 \mathrm{~km}^{2}$ connecting the Bohai Sea with open waters - the East China Sea; the Bohai Sea with an area of about $77000 \mathrm{~km}^{2}$, may be also considered to be part of the large Yellow Sea ecosystem (UNDP, 2007). The surrounding areas of the large Yellow Sea have experienced strong disturbance from human activities, e.g., urbanization, industry, agriculture 15 and aquaculture, with the rapid economic development of China in the past decades. Coastal anthropization caused that large amounts of nitrogen and phosphorus as well as other pollutants have been discharged into the basin, and the aquatic ecological system has been facing a serious problem of degradation (SOA, 2010; Wang et al., 2011). Field work was carried out to investigate the macroalgal blooms at the coast of Yantai, Qingdao and the Northern Jiangsu Shoal, and in the Yellow Sea in 2007, 2008, 2009, 2010 and 2014.

\subsection{Area-weighted water quality level}

Eutrophication index or composite pollution index - CPI can be used to evaluate the pollution status of a given water body, especially with the issue of eutrophication (SOA,
2011; Zou, 1985; Xiao et al., 2007; Chen et al., 2007). As coastal water quality in China
BGD

$11,7029-7054,2014$

Eutrophication

behind the

world-largest floating

macroalgal blooms

Q. Xing

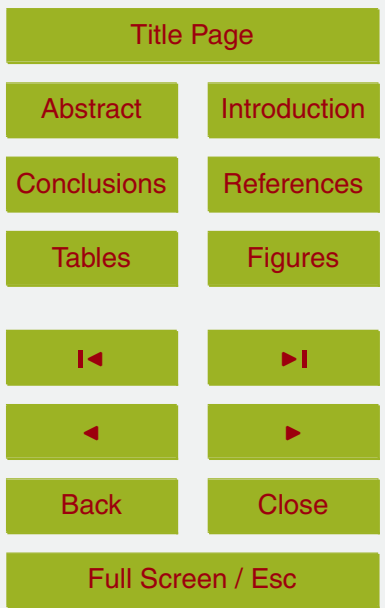

Printer-friendly Version

Interactive Discussion 
have been dominated by nutrient pollution (SOA, 2010, 2011, 2013), an area-weighted nutrient pollution index (AWCPI-NP) was proposed (Xing et al., 2011b) to evaluate the overall water quality status in regional waters which can be classified as different water bodies with different water quality levels, see Eq. (1):

$5 \quad$ AWCPI-NP $=\sum_{i=2}^{5} N_{i} \cdot P_{i} \cdot A_{i}$

where $i$ is the water quality level of polluted waters, $N_{i}$ is the lower limit of TIN-N concentration $\left(\mathrm{mg} \mathrm{L}^{-1}\right)$ at the level $i$, and the same with $P_{i}$, the lower limit of $\mathrm{PO}_{4}-\mathrm{P}$ concentration $\left(\mathrm{mgL}^{-1}\right)$ at this level (Table 1). $A_{i}$ is the corresponding area of water body at this level $\left(\mathrm{km}^{2}\right)$.

The yearly AWCPI-NP was calculated using Eq. (1). As data before 2001 was not available, only the data of water quality level $(i)$ and its area $\left(A_{i}\right)$ since 2001 were collected from the annual reports of SOA, China. For the Yellow Sea, we have no water quality data about the coastal waters near Korean Peninsula, and so the AWCPI-NP was calculated based on the water quality data from China. Taking the population, watershed and other factors into account, it is safe to hypothesize that the AWCPI-NP at the western Korean coastal waters will not decrease, which will not influence the results of time series analysis in AWCPI-NP.

\subsection{Mapping floating macro-algae}

20 Floating macroalgae has the similar spectral characteristics to vegetations, and so the widely used normalized difference vegetation index (NDVI) can be applied to extract the macroalgae patches, or other similar indices (Hu et al., 2009) can be used. In this work, Moderate-Resolution Imaging Spectroradiometer (MODIS terra/aqua) reflectance products with a resolution of $500 \mathrm{~m}$ were used. After MODIS imageries were georeferenced, the band $1 \#(840-875 \mathrm{~nm})$ and $2 \#(620-670 \mathrm{~nm})$ were used to generate the NDVI images. The NDVI was calculated as Eq. (2). A threshold value of NDVI 7033
BGD

$11,7029-7054,2014$

Eutrophication

behind the

world-largest floating

macroalgal blooms

Q. Xing

Title Page

Abstract

Introduction

Conclusions

Tables

References

Figures

14

4

Back

Close

Full Screen / Esc

Printer-friendly Version

Interactive Discussion $\rightarrow$

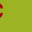

in

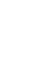


was set to identify the floating macroalgae patches; due to the impacts from clouds, haze, sun glints, water background, a strategy of dynamic NDVI threshold was used to extract macroalgae patches (Xing et al., 2011a; Cui et al., 2013). Finally the maximum MODIS-derived daily distributions of macroalgae from 2007 to 2013 were calculated.

$5 \quad \mathrm{NDVI}=($ band $1-$ band2 $) /($ band $1+$ band2 $)$

\subsection{Satellite-derived $\mathrm{Chl}$ a data}

The annual Chl a concentration with a $9 \mathrm{~km} \times 9 \mathrm{~km}$ spatial resolution was obtained from the satellite imaging products of Sea-viewing Wide Field-of-view Sensor (SeaWIFS) and MODIS aqua (data available: http://oceancolor.gsfc.nasa.gov). The Chl a data were derived from SeaWiFS and MODIS aqua imageries on the basis of the algorithm developed by O'Reilly et al. (1998). To avoid the uncertainties in satellite-derived $\mathrm{Chl}$ - a products in the turbid waters, we extracted the average of $\mathrm{Chl} a$ at the middle of the Yellow Sea $\left(123-125^{\circ} \mathrm{E}, 34-36^{\circ} \mathrm{N}\right)$ as well as the Bohai Sea $\left(120-120.5^{\circ} \mathrm{E}, 38.25-\right.$ $38.75^{\circ} \mathrm{E}$ ) during the 1998-2012 period (Fig. 1): (a) MODIS data: 2002-2012; (b) SeaWIFS: 1998-2010. The systematic bias between the SeaWIFS Chl $a$ and the MODIS Chl a was corrected through Eq. (3), and then, the corrected SeaWIFS Chl a from 1998 to 2002 and the MODIS Chl a from 2003 to 2012 were used to generate a yearly time series of satellite-derived $\mathrm{Chl} a$.

20 SeaWIFS Chl $a, \mu g L^{-1}=1.0772 \times$ MODIS Chl $a+0.0961$

\subsection{Other data}

Monthly Sea Surface Temperature (SST), and Photosynthesis Active Radiation (PAR) of detected by MODIS terra were used for investigating the water temperature and solar radiation (data available: http://oceancolor.gsfc.nasa.gov). To investigate the impacts of runoff on the Yellow Sea and the Bohai Sea, precipitation data from 1998 to 2009 in the two coastal regions were extracted from the Tropical Rainfall Measuring 7034
BGD

$11,7029-7054,2014$

Eutrophication

behind the

world-largest floating

macroalgal blooms

Q. Xing

Title Page

Abstract

Introduction

Conclusions

Tables

References

Figures

14

4

Back

Full Screen / Esc

Printer-friendly Version

Interactive Discussion
$>$ I

Close 
Mission (TRMM) Microwave Imager precipitation products: (a) the west coastal region of the Yellow Sea $\left(117-122^{\circ} \mathrm{E}, 32-37^{\circ} \mathrm{N}\right)$; (b) the Bohai coastal region $\left(115-123^{\circ} \mathrm{E}\right.$, $36-42^{\circ} \mathrm{N}$ ), which had been calibrated and rescaled to monthly data (3B43) on the $0.25^{\circ} \times 0.25^{\circ}$ grid (Huffman, 2007). To analyze the trends in precipitation, a 12-point 5 running average was used to remove the impacts of seasonal fluctuations.

\section{Results}

\subsection{World-largest super floating macroalgae blooms}

The maximum daily covered areas from 2007 to 2013, derived from satellite imageries, show that floating macroalgae mainly occurred in the west of the Yellow Sea and to the north of the Jiangsu Shoal (Fig. 1). The Jiangsu Shoal was the source of macroalgae and its waters was highly eutrophicated due to the nutrient input discharge of anthropogenic activities (Liu et al., 2012), but the turbid water conditions with the lowest Secchi depth of $0.1 \mathrm{~m}$, limited the rapid growth of macroalgae (Xing et al., 2011a).

Especially from 2008, the bloom scale increased by several to ten folds. In the sum15 mer of 2008, the world-largest macroalgal blooms of Ulva prolifera drifted from the middle of southern part of the Yellow Sea and hit the Qingdao City (Xing et al., 2009; Liu et al., 2009; Zheng et al., 2011), covering an area of $1200 \mathrm{~km}^{2}$ in total (Table 2) and impacting as many as $40000 \mathrm{~km}^{2}$ of sea surface; and, only from a part of the coast of Qingdao, more than 1000000 tons of biomass were collected (Xing et al., 2011a). This bloom scale is much larger than any other places in the world, e.g., Italy, France, Australia (Menesguen, 2006; Morand and Briand, 1996); and the conservatively collected iomass of green algae in 2008 is also larger than that of floating sargasum in a recent large scale bloom (Gower and King, 2011; Smetacek and Zingone, 2013).
BGD

$11,7029-7054,2014$

Eutrophication

behind the

world-largest floating

macroalgal blooms

Q. Xing

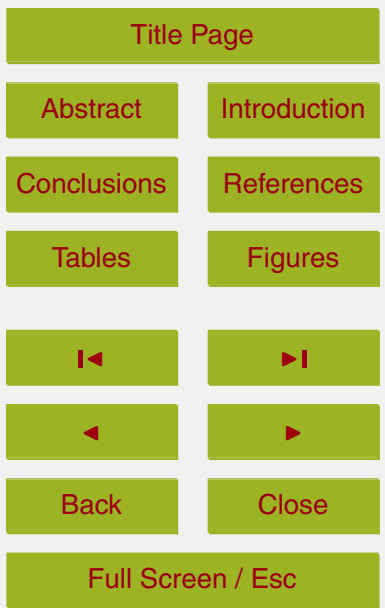

Printer-friendly Version

Interactive Discussion 


\subsection{Progressive nutrient pollution behind the MAB}

In the semi-enclosed region of the Yellow Sea and the Bohai Sea, the polluted areas characterized by different water quality levels fluctuated yearly without a significant trend during the 2001-2012 period (Fig. 2): in the Yellow Sea, the area of relatively 5 clean waters (Level II) deceased by about $50 \%$ while the Level V (heavily polluted waters) increased sharply, and there were no significant trends in the polluted (Level III) and slightly polluted waters (Level II); and from this information, it is difficult to assess the overall trophic status. The application of the area-weighted eutrophication index or nutrient pollution index (AWCPI-NP) overcomes the method previously used

10 (Xing et al., 2011b); Fig. 2c and d show the AWCPI-NP changed in the Yellow Sea and the Bohai Sea. Both the Yellow Sea and the Bohai Sea experienced an increase in nutrient pollution, especially the latter increased by one fold from 2001 to 2007.

The annual values of AWCPI-NP from 2001 to 2012 (Fig. 2c) show a significant high level of nutrient status since 2004 in the semi-enclosed region $(p<0.01, F$ test). The

15 large-scale floating macroalgal blooms, happened every summer since 2007 , and the averaged AWCPI-NP in 2007-2012 (MAB phase) is larger by about $45 \%$ than that in 2001-2006 (pre-MAB phase), and nearly three times of that in 2001-2003. These results supports that the eutrophicating process in the Yellow Sea might lead to the macroalgal blooms. When the AWCPI-NP is normalized by the enclosed area, we can find that the Bohai Sea has a higher trophic status than the Yellow Sea (Fig. 2d). We can expect that the net nutrients flux are generally from the polluted nearshore waters to clean offshore waters and from the inner semi-enclosed region (the Bohai Sea) to outer part (the southern Yellow Sea).

Records (SOA, 2013; JSOF, 2012) show that polluted sea water in Jiangshu province 25 (coastal water along the Jiangsu Shoal, Fig. 1c) increased rapidly by more than one fold from 2003 to 2011, and its contribution to the pollution in the Yellow Sea also increased, e.g., more than $60 \%$ in 2007 (Fig. 3a). Meanwhile, the nitrogen and phosphorus concentration increased significantly from 2000 to 2011 (Fig. 3b); especially, the
BGD

$11,7029-7054,2014$

Eutrophication

behind the

world-largest floating

macroalgal blooms

Q. Xing

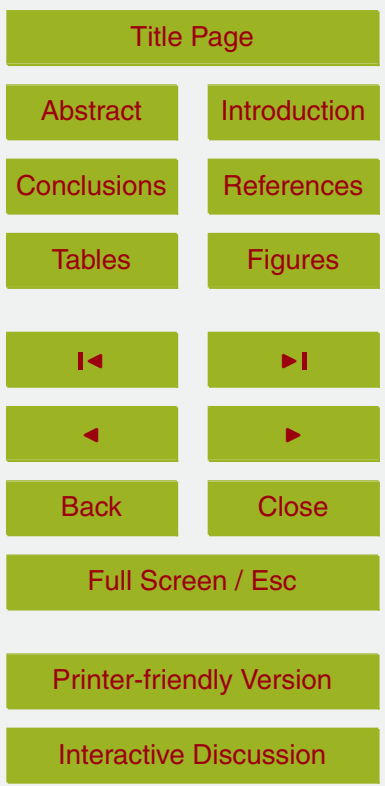


active phosphorus $\left(\mathrm{PO}_{4}-\mathrm{P}\right)$ increased by three folds from 2000 to 2011 . The Jiangsu shoal is the "seedbed" providing the seeds of macroalgae which might be attached to the aquaculture facilities, tidal flat, or existed as germlings in seawater or sediments (Liu et al., 2009; Hu et al., 2010; Pang et al., 2010; Zhang et al., 2011); with this eu5 trophication, more seeds might be released under human or natural disturbance, e.g., seaweeds harvesting, bottom shears of tidal and/or wind-driven currents, and led to the world-largest super MAB in the Yellow Sea. Much smaller scale of MAB with the covering area of lower than $60 \mathrm{~km}^{2}$, happened during the 2000-2006 period at the Jiangshu Shoal and the East China Sea (Hu et al., 2010), which is consistent with low the trophic 10 status in that period.

These agreements in the increases in nutrient pollution, $\mathrm{Chl}$ a and macroalgae bloom scales, suggest that the progressive eutrophication drove the super MAB in recent years.

\subsection{Eutrophication indicated by Chl-a}

15 The Chl a had a pronounced increase in the centers of both the Yellow Sea $(p<0.01)$ and the Bohai Sea $(p<0.001)$ (Fig. 4a). The Chl $a$ at the center of the Yellow Sea $(p<0.005)$ was much lower than that at the Bohai Sea, which is consistent with the distribution of eutrophic status indicated by the AWCPI-NP, i.e. the overall eutrophic status of the large semi-enclosed basin, which suggests that the increase in phytoplankton biomass in 2001-2012 was driven by the increase in nutrients. The Chl $a$ in the west of southern Yellow Sea $\left(35.5-36^{\circ} \mathrm{N}, 121.25-121.75^{\circ} \mathrm{E}\right.$, Box C in Fig. 1) where the super macroalgal blooms outbroke in every summer from 2007, also increased during the 1998-2012 period.

Compared to the inner part (the Bohai Sea, $p<0.01$ ) of the entire large Yellow Sea 25 basin, a low correlation was observed between the Chl $a$ and the AWCPI-NP in the outer part (the Yellow Sea) (Fig. 4b), which may be mainly due to the following reasons: (a) the AWCPI-NP in the Yellow Sea was not so soundly calculated (as mentioned in the section of methods); (b) the waters from the East China Sea may lead to the

Eutrophication

behind the

world-largest floating macroalgal blooms

Q. Xing

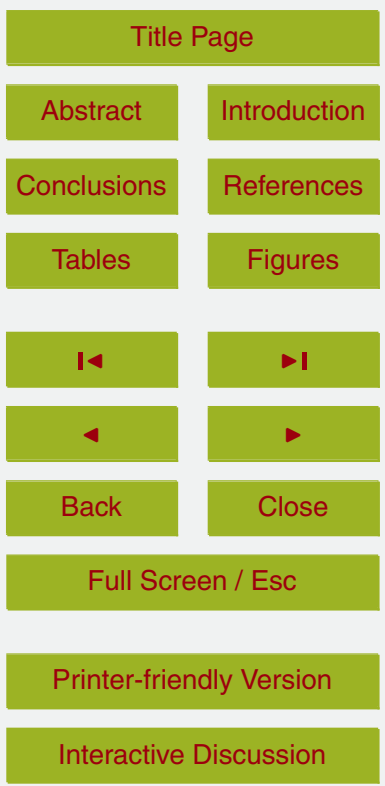


fluctuations in nutrients and temperature in the center of the Yellow Sea (Box A in Fig. 1); and (c) macroalgal blooms may affect phytoplankton in the ways of nutrientcompetitions and so on. At the center of the Yellow Sea, the Chl a lower than $1.5 \mathrm{\mu g} \mathrm{L}^{-1}$ had a high correlation with the AWCPI-NP $(p<0.01)$ (Fig. 3b), which might imply that 5 the less eutrophicated waters were sensitive to the nutrient input.

The floating macroalgae could cause false values in the satellite-derived Chl a (Xing et al., 2014). The annual $\mathrm{Chl}$ a concentration in the MAB phase was higher than that in the pre-MAB phase by $16 \%$; when the months (June, July, August) with possible impact of floating algae were excluded, a rise of $15 \%$ in Chl a was still observed from 10 the pre-MAB to MAB phase. These results suggest that a progressive eutrophication existed behind the super MAB and that the MAB did not change the eutrophication trend. Satellite-derived optical indices in addition to $\mathrm{Chl} a$, also suggested an increase in the portion of phytoplankton particles in the southern Yellow Sea (Xing et al., 2012).

As indicated by $\mathrm{Chl}$ a, trophic status both in the middle southern Yellow Sea (Box A) 15 and the offshore waters in the East China Sea (Box ECS in Fig. 1c), were lower than that in southwest of Yellow Sea (Box C), especially by $50 \%$ in the summer season. Macroalgae from the Jiangsu shoal visited the two regions (Hu et al., 2010; Xing et al., 2011a), but the bloom scales were very small, which also suggests that trophic status regulated the scale of macroalgal blooms in China coastal waters.

\section{Discussion and concluding remarks}

The eutrophication trend indexed by the Chl a was consistent with the contemporary increasing trend in the AWCPI-NP and the fact of the continuous super macroalgal blooms in the Yellow Sea. The increase in Chl $a$ in the Yellow Sea and the Bohai Sea in the 1998-2006 period was opposite of the decreasing trend at the low-latitude zone of global open oceans where the nutrients were reduced because of the enhanced seawater stratification driven by climate event - El Niño/Southern Oscillation (ENSO) (Behrenfeld et al., 2006). The increase in Chl $a$ in coastal waters was most likely to be
BGD

11, 7029-7054, 2014

Eutrophication

behind the

world-largest floating

macroalgal blooms

Q. Xing

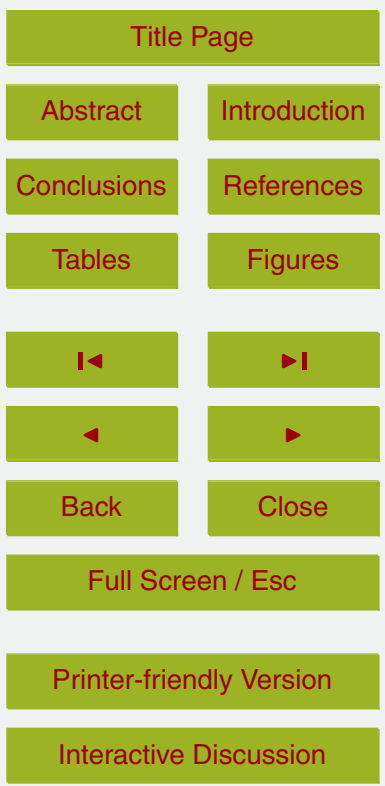


driven by the local eutrophication due to the input of excess nutrient because of human activities (Morand and Briand, 1996; Seitzinger et al., 2005).

Coastal zones in China have experienced a rapid process of urbanization and industrialization especially in the past thirty years since the beginning of opening-up 5 economic policy in China ( $\mathrm{He}$ et al., 2006). Magnitude of human disturbance in these areas have been increasing, and large amounts of anthropogenic pollutants (including nutrients) have been discharged into rivers and then into coastal waters. For example, the river nitrate flux in the Yangtze River basin increased about ten folds from 1968 to 1997 (Yan et al., 2003). The reports on China marine environment from 1992 to 2012 10 (SOA, 2010, 2011, 2013), also showed that the total area of unclean waters increased in the past 20 years, which were mainly due to nutrient pollution. The Yellow Sea and the Bohai Sea experienced a large amount of nutrients input due to human activities such as agriculture and aquaculture, especially at the Jiansu shoal. In addition to the anthropogenic perturbation in surrounded land regions with rapid economic development, the climatic variations of the precipitation increase in the coastal regions (Fig. 5) tended to bring more nutrients to coastal waters through runoff, wet precipitation and possible submarine groundwater discharge, and thus contribute to the increase in the AWCPI-NP.

Natural variations in water temperature, light conditions, can lead to the changes 20 in the growth of phytoplankton, and, the increased Chl $a$ in this way may not suggest an eutrophication process. With the comparison between the macroalgal bloom phase (2008-2013) and the pre-bloom phase (2001-2006), neither the Sea Surface Temperature (SST) nor the Photosynthesis Active Radiation (PAR) had significant shift (see Fig. 6). This fact suggests that SST and PAR were not likely the driving factors for the increase in phytoplankton or the outbreak of macroalgal blooms. Herbivorous zooplankton grazing can regulate the accumulation of phytoplankton (Behrenfeld and Boss, 2014), thus less grazing pressure rather than the eutrophication may lead to the increase in the biomass of phytoplankton $(\mathrm{Chl} \mathrm{a})$. However, the spatial contrast in Chl a, e.g., high $\mathrm{Chl} a$ in the Bohai Sea (Box B), moderate Chl $a$ in southwest of Yellow Sea
BGD

$11,7029-7054,2014$

Eutrophication

behind the

world-largest floating

macroalgal blooms

Q. Xing

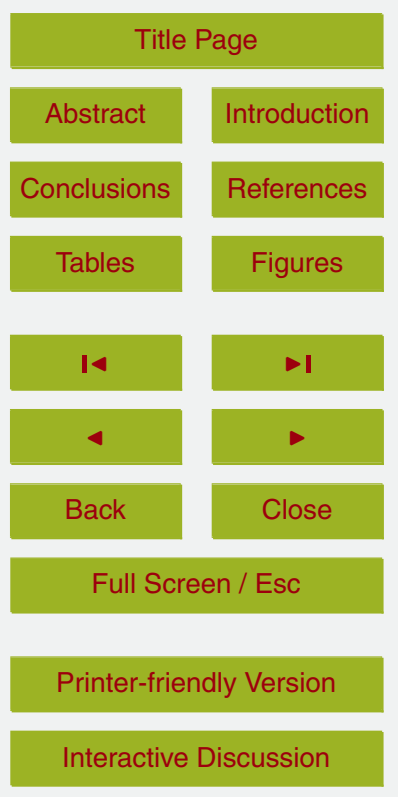


(Box C), and low Chl a in the middle of Yellow Sea (Box A) or East China Sea (Box ECS), suggests that the trophic status rather than zooplankton dominate the spatial distribution in Chl a; and, according to the reports of UNDP (United Nations Development Programme) $(2007,2011)$ on the Yellow Sea Large Marine System (YSLMS), no 5 reports suggested a decrease in zooplankton biomass in this region.

Overall, twelve years of AWCPI-NP and Chl a data show that the Yellow Sea was facing a progressive eutrophication, and macroalgal blooms coincided with high levels of nutrient pollution. The expansion of $P$. yezoensis aquaculture were thought to lead to the world-largest macroalgal blooms in the Yellow Sea (Liu et al., 2009; Hu et al., 10 2010); in this view, there should be blooms before 2007 and their scales should be able to be predicted by the scale of aquaculture (e.g., the area) to which the seed population (Smetacek and Zingone, 2013) can be regarded to be linear proportional. However, there were no such floating macroalgal blooms observed in the Yellow Sea near Qingdao even with high spatial satellite images (Hu et al., 2010; Xing et al., 2011a). 15 Increased aquaculture scale wouldn't likely dominate the non-linear outburst in the biomass of macroalgae, e.g., the green tides in 2008, but increased nutrient supply would by improving the growth rate (Smetacek and Zingone, 2013) when the nutrient level reaches the threshold for blooms, like the red tide of phytoplankton. We can speculate that the large scale macroalgal blooms since 2007 is the result of cumulative effect of eutrophication, i.e. over enrichment of nutrients.

As the current water trophic status is at a high level, if there is no significant change in the environmental conditions, we speculate that the large scale algal blooms in the Yellow Sea would not disappear unless the nutrients input can be effectively reduced. In fact, MODIS imagery show that a small scale of green tide was forming in 25 the Souther Yellow Sea on 3 May, 2014, which covered about $50 \mathrm{~km}^{2}$ of sea surface and was expected to increase in the coming summer. The averages of TIN and $\mathrm{PO}_{4}-\mathrm{P}$ in macroalgae-dominated waters (southwest of Yellow Sea) during the bloom of 2008 were 14.89 and $0.27 \mu \mathrm{molL}^{-1}$, respectively (Xia et al., 2009), which implied a limitation of phosphorus and general clean waters against China national marine quality criteria
BGD

$11,7029-7054,2014$

Eutrophication

behind the

world-largest floating

macroalgal blooms

Q. Xing

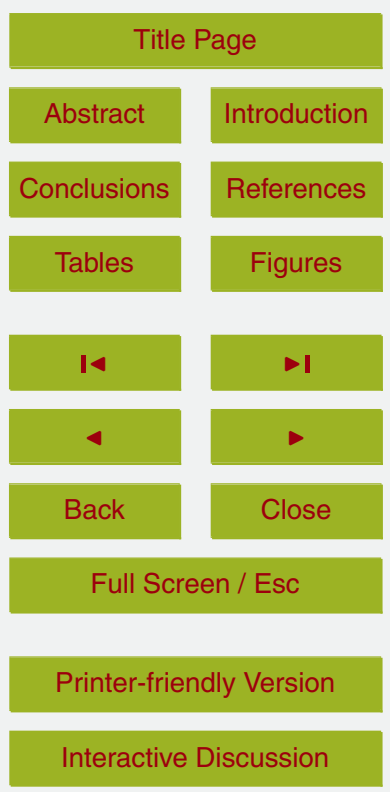


(MEP, 1997). So in this view, we should study and know the nutrient thresholds for macroalgae blooms and evaluate the economic possibilities before we take countermeasures to cut off nutrient input if it is necessary.

In addition, such world-largest super MABs have been occurring in a semi-enclosed 5 basin, which should alert us to the MAB-associated ecological consequences in the Yellow Sea. Results here suggest that the occurrence of drifting macroalgae in the Yellow Sea did not cause the decrease in the annual phytoplankton biomass, but might alter the bloom of phytoplankton in summer and early autumn, and thus more unknown related ecological consequences should be studied.

10 Acknowledgements. This work was supported by projects from the Chinese Academy of Sciences (Nos XDA11020403, XDA11020102, KZCX2-EW-QN209) and the CAS/SAFEA International Partnership Program for Creative Research Teams and the YIC-CAS/ISMAR-CNR cooperation program. We especially thank the Institute of Oceanology, Chinese Academy of Sciences for organizing the open cruise in the Yellow Sea, and Yanju Hao, Dingfeng Yu and 15 Mingjing Lou for performing the field sampling, observations and data collection.

\section{References}

Behrenfeld, M. J. and Boss, E. S.: Resurrecting the ecological underpinnings of ocean plankton blooms, Annu. Rev. Mar. Sci., 6, 167-194, doi:10.1146/annurev-marine-052913-021325, 2014.

Behrenfeld, M. J., O'Malley, R. T., Siegel, D. A., McClain, C. R., Sarmiento, J. L., Feldman, G. C., Milligan, A. J., Falkowski, P. G., Letelier, R. M., and Boss, E. S.: Climate-driven trends in contemporary ocean productivity, Nature, 444, 752-755, doi:10.1038/Nature05317, 2006.

Bot, P. V. M. and Colijn, F.: A method for estimating primary production from chlorophyll concentrations with results showing trends in the Irish Sea and the Dutch coastal zone, Ices J.

$25 \quad$ Mar. Sci., 53, 945-950, doi:10.1006/jmsc.1996.0116, 1996.

Cai, W. J., Hu, X. P., Huang, W. J., Murrell, M. C., Lehrter, J. C., Lohrenz, S. E., Chou, W. C., Zhai, W. D., Hollibaugh, J. T., Wang, Y. C., Zhao, P. S., Guo, X. H., Gundersen, K., Dai, M. H., and Gong, G. C.: Acidification of subsurface coastal waters enhanced by eutrophication, Nat. Geosci., 4, 766-770, doi:10.1038/Ngeo1297, 2011.

\section{1}

BGD

$11,7029-7054,2014$

Eutrophication

behind the

world-largest floating

macroalgal blooms

Q. Xing

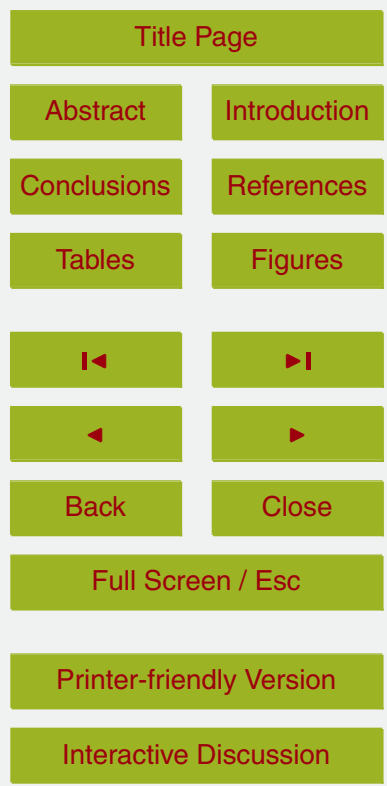


Carlson, R. E.: A trophic state index for lakes, Limnol. Oceanogr., 22, 361-369, 1977.

Chen, C. Q., Tang, S. L., Pan, Z. L., Zhan, H. G., Larson, M., and Jonsson, L.: Remotely sensed assessment of water quality levels in the Pearl River Estuary, China, Mar. Pollut. Bull., 54, 1267-1272, doi:10.1016/j.marpolbul.2007.03.010, 2007.

5 Cui, T. W., Cao, W. X., Zhang, J., Hao, Y. L., Yu, Y. G., Zu, T. T., and Wang, D. X.: Diurnal variability of ocean optical properties during a coastal algal bloom: implications for ocean colour remote sensing, Int. J. Remote Sens., 34, 8301-8318, doi:10.1080/01431161.2013.833356, 2013

Egge, J. K. and Aksnes, D. L.: Silicate as regulating nutrient in phytoplankton competition, Mar. Ecol. Prog. Ser., 83, 281-289, doi:10.3354/Meps083281, 1992.

Ferreira, J. G., Andersen, J. H., Borja, A., Bricker, S. B., Camp, J., da Silva, M. C., Garces, E., Heiskanen, A. S., Humborg, C., Ignatiades, L., Lancelot, C., Menesguen, A., Tett, P., Hoepffner, N., and Claussen, U.: Overview of eutrophication indicators to assess environmental status within the European Marine Strategy Framework Directive, Estuar. Coast. Shelf. S., 93, 117-131, doi:10.1016/j.ecss.2011.03.014, 2011.

Gao, X. L. and Song, J. M.: Phytoplankton distributions and their relationship with the environment in the Changjiang Estuary, China, Mar. Pollut. Bull., 50, 327-335, doi:10.1016/j.marpolbul.2004.11.004, 2005.

Garcia-Pintado, J., Martinez-Mena, M., Barbera, G. G., Albaladejo, J., and Castillo, V. M.: Anthropogenic nutrient sources and loads from a Mediterranean catchment into a coastal lagoon: Mar Menor, Spain (vol 373, pg 220, 2007), Sci. Total Environ., 384, 498-498, doi:10.1016/j.scitotenv.2007.05.038, 2007.

Gower, J. and King, S.: Distribution of floating Sargassum in the Gulf of Mexico and the Atlantic Ocean mapped using MERIS, Int. J. Remote Sens., 32, 1917-1929, 2011.

He, Z., Xing, Q., Shi, H., and Pan, W.: Application of remote sensing technology on regional environment monitoring in Daya Bay, Ecologic Sci., 25, 371-374, 384, 2006.

Hecky, R. E. and Kilham, P.: Nutrient limitation of phytoplankton in fresh-water and marine environments - a review of recent-evidence on the effects of enrichment, Limnol. Oceanogr., 33, 796-822, 1988.

$30 \mathrm{Hu}, \mathrm{C} . \mathrm{M}$.: A novel ocean color index to detect floating algae in the global oceans, Remote Sens. Environ., 113, 2118-2129, doi:10.1016/j.rse.2009.05.012, 2009.

$\mathrm{Hu}, \mathrm{C}$. and He, M. X.: Origin and offshore extent of floating algae in Olympic sailing area, Eos Trans. AGU, 89, 302-303, 2008.

BGD

$11,7029-7054,2014$

Eutrophication

behind the

world-largest floating

macroalgal blooms

Q. Xing

Title Page

Abstract

Introduction

Conclusions

Tables

References

Figures

14

4

Back

Close

Full Screen / Esc

Printer-friendly Version

Interactive Discussion 
Hu, C. M., Li, D. Q., Chen, C. S., Ge, J. Z., Muller-Karger, F. E., Liu, J. P., Yu, F., and He, M. X.: On the recurrent Ulva prolifera blooms in the Yellow Sea and East China Sea, J. Geophys. Res.-Oceans, 115, C05017, doi:10.1029/2009jc005561, 2010.

Huffman, G. J., Adler, R. F., Bolvin, D. T., Gu, G. J., Nelkin, E. J., Bowman, K. P., Hong, Y., Stocker, E. F., and Wolff, D. B.: The TRMM multisatellite precipitation analysis (TMPA): quasiglobal, multiyear, combined-sensor precipitation estimates at fine scales, J. Hydrometeorol., 8, 38-55, doi:10.1175/Jhm560.1, 2007.

JSOF (JiangSu Provincial Department of Ocean and Fisheries): Bulletin of Marine Environmental Quality of Jiansu Province in 2011, 2011.

10 Kauffman, G. J. and Belden, A. C.: Water quality trends (1970 to 2005) along Delaware streams in the Delaware and Chesapeake Bay watersheds, USA, Water Air Soil Poll., 208, 345-375, doi:10.1007/s11270-009-0172-z, 2010.

Keesing, J. K., Liu, D. Y., Fearns, P., and Garcia, R.: Inter- and intra-annual patterns of Ulva prolifera green tides in the Yellow Sea during 2007-2009, their origin and relationship to the expansion of coastal seaweed aquaculture in China, Mar. Pollut. Bull., 62, 1169-1182, doi:10.1016/j.marpolbul.2011.03.040, 2011.

Liu, D. Y., Keesing, J. K., Xing, Q. G., and Shi, P.: World's largest macroalgal bloom caused by expansion of seaweed aquaculture in China, Mar. Pollut. Bull., 58, 888-895, doi:10.1016/j.marpolbul.2009.01.013, 2009.

20 Liu, F., Pang, S., Chopin, T., Gao, S., Shan, T., Zhao, X., and Li, J.: Understanding the recurrent large-scale green tide in the Yellow Sea: Temporal and spatial correlations between multiple geographical, aquacultural and biological factors, Mar. Environ. Res., 83, 38-47, doi:10.1016/j.marenvres.2012.10.007, 2012.

LOICZ: Land-based nutrient pollution and the relationship to harmful algal blooms in the coastal marine systems, land-ocean interactions in the coastal zone, Inprint, 3, 14-16, 2008.

Lund, J. W.: Eutrophication, Nature, 214, 557-558, doi:10.1038/214557a0, 1967.

Menesguen, A., Cugier, P., and Leblond, I.: A new numerical technique for tracking chemical species in a multisource, coastal ecosystem applied to nitrogen causing Ulva blooms in the Bay of Brest (France), Limnol. Oceanogr., 51, 591-601, 2006.

30 MEP (Ministry of Environmental Protection of China): Sea Water Quality Standard (GB30971997), 1997.

Morand, P. and Briand, X.: Excessive growth of macroalgae: a symptom of environmental disturbance, Bot. Mar., 39, 491-516, doi:10.1515/botm.1996.39.1-6.491, 1996.
BGD

$11,7029-7054,2014$

Eutrophication

behind the

world-largest floating

macroalgal blooms

Q. Xing

Title Page

Abstract

Introduction

Conclusions

Tables

References

Figures

14

4

Back

Full Screen / Esc

Printer-friendly Version

Interactive Discussion 
O’Reilly, J. E., Maritorena, S., Mitchell, B. G., Siegel, D. A., Carder, K. L., Garver, S. A., Kahru, M., and McClain, C.: Ocean color chlorophyll algorithms for SeaWiFS, J. Geophys. Res.-Oceans, 103, 24937-24953, doi:10.1029/98jc02160, 1998.

Pang, S. J., Liu, F., Shan, T. F., Xu, N., Zhang, Z. H., Gao, S. Q., Chopin, T., and Sun, S.: 5 Tracking the algal origin of the Ulva bloom in the Yellow Sea by a combination of molecular, morphological and physiological analyses, Mar. Environ. Res., 69, 207-215, doi:10.1016/j.marenvres.2009.10.007, 2010.

Qu, M., Xing, Q., and Pan, W.: Parameters of monitoring Daya Bay water quality by remote sensing, Ecologic Sci., 25, 262-265, 2006.

10 Seitzinger, S. P., Harrison, J. A., Dumont, E., Beusen, A. H. W., and Bouwman, A. F.: Sources and delivery of carbon, nitrogen, and phosphorus to the coastal zone: an overview of Global Nutrient Export from Watersheds (NEWS) models and their application, Global Biogeochem. Cy., 19, Gb4s01, doi:10.1029/2005gb002606, 2005.

Smetacek, V. and Zingone, A.: Green and golden seaweed tides on the rise, Nature, 504, 8488, doi:10.1038/Nature12860, 2013.

SOA (State Oceanic Administration of China): Bulletin of the Marine Environmental Status of China for the Year of 2010, 2010.

SOA (State Oceanic Administration of China): Bulletin of the Marine Environmental Status of China for the Year of 2011, 2011.

20 SOA (State Oceanic Administration of China): Marine Environment Information, 2013.

Sun, S., Wang, F., Li, C. L., Qin, S., Zhou, M. J., Ding, L. P., Pang, S. J., Duan, D. L., Wang, G. C., Yin, B. S., Yu, R. C., Jiang, P., Liu, Z. L., Zhang, G. T., Fei, X. G., and Zhou, M.: Emerging challenges: massive green algae blooms in the Yellow Sea, Nature Preced., doi:10101/npre.2008.2266.1, 2008.

Turner, R. E. and Rabalais, N. N.: Coastal eutrophication near the Mississippi River Delta, Nature, 368, 619-621, doi:10.1038/368619a0, 1994.

UNDP: Fourth Meeting of the Regional Scientific and Technical Panel for the UNDP/GEF Yellow Sea Project Guangzhou, China, 26-28 November 2007, 2007.

UNDP: Reducing Environmental Stress in the Yellow Sea Large Marine Ecosystem, Final Evaluation Report, edited by: Kullenberg, G. and Huber, M. E., 2011.

Wang, B., Xie, L., and Sun, X.: Water quality in marginal seas off China in the last two decades, Int. J. Oceanogr., doi:10.1155/2011/731828, 2011.
BGD

11, 7029-7054, 2014

Eutrophication

behind the

world-largest floating

macroalgal blooms

Q. Xing

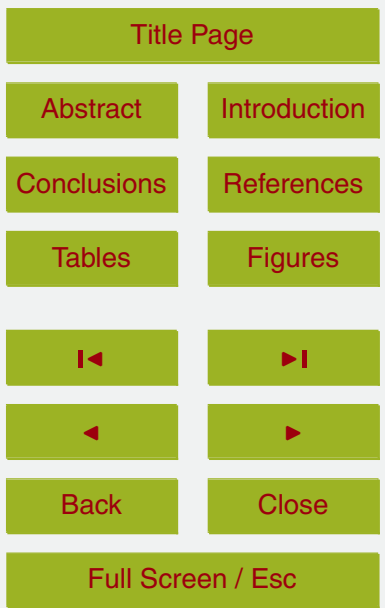

Printer-friendly Version

Interactive Discussion 
Xia, B., Ma, S. S., Cui, Y., Chen, B. J., Chen, J. F., Song, Y. L., and Jiang, Z. J.: Distribution of temperature, salinity, dissolved oxygen, nutrients and their relationships with green tide in Enteromorpha prolifera outbreak area of the Yellow Sea, Progress in Fishery Sciences, 30, 94-101, 2009.

5 Xiao, Y. J., Ferrerira, J. G., Bricker, S. B., Nunes, J. P., Zhu, M. Y., and Zhang, X. L.: Trophic assessment in Chinese coastal systems - review of methods and application to the Changjiang (Yangtze) Estuary and Jiaozhou Bay, Estuar. Coast., 30, 901-918, 2007.

Xing, Q., Loisel, H., Schmitt, F., Shi, P., Liu, D., and Keesing, J.: Detection of the Green Tide at the Yellow Sea and Tracking its Wind-forced Drifting by Remote Sensing, Geophysical

10 Research Abstracts 11, EGU2009-577, EGU General Assembly 2009, Vienna, 2009.

Xing, Q. G., Zheng, X. Y., Shi, P., Hao, J. J., Yu, D. F., Liang, S. Z., Liu, D. Y., and Zhang, Y. Z.: Monitoring "Green Tide" in the Yellow Sea and the East China Sea using multitemporal and multi-source remote sensing images, Spectrosc. Spect. Anal., 31, 1644-1647, doi:10.3964/j.issn.1000-0593(2011)06-1644-04, 2011a.

Xing, Q., Li, L., Yu, D., Shi, P., and Hou, X.: Trends in chlorophyll a concentration and its relationship to an area-weighted water quality index at the Bohai Sea, China, EMECS9: Managing for Results in Our Coastal Seas, 28-31 August, Baltimore, Maryland, USA, 2011b.

Xing, Q. G., Loisel, H., Schmitt, F. G., Dessailly, D., Hao, Y. J., Han, Q. Y., and Shi, P.: Fluctuations of satellite-derived chlorophyll concentrations and optical indices at the Southern Yellow

20 Sea, Aquat. Ecosyst. Health, 15, 168-175, doi:10.1080/14634988.2012.688480, 2012.

Xing, Q. G., Tang, S. L., Tang, D. L., Tian, L. Q. , Wang, X. H., Lou, M. J., Braga, F., and Tosi, L.: Chlrophyll a concentration altered by super macroalgal blooms in the Yellow Sea: satellite observations, in preparation, 2014.

Yan, W. J., Zhang, S., Sun, P., and Seitzinger, S. P.: How do nitrogen inputs to the Changjiang basin impact the Changjiang River nitrate: a temporal analysis for 1968-1997, Global Biogeochem. Cy., 17, 1091-1100, doi:10.1029/2002gb002029, 2003.

Zhang, X. W., Xu, D., Mao, Y. Z., Li, Y. X., Xue, S. Y., Zou, J., Lian, W., Liang, C. W., Zhuang, Z. M., Wang, Q. Y., and Ye, N. H.: Settlement of vegetative fragments of Ulva prolifera confirmed as an important seed source for succession of a large-scale green tide bloom,

Zheng, X., Xing, Q., Shi, P., and Li, L.: Numerical simulation of the 2008 green tide in the Yellow Sea, Mar. Sci., 35, 82-87, 2011.

BGD

11, 7029-7054, 2014

Eutrophication

behind the

world-largest floating

macroalgal blooms

Q. Xing

Title Page

Abstract

Introduction

Conclusions

Tables

References

Figures

14

4

Back

Close

Full Screen / Esc

Printer-friendly Version

Interactive Discussion 
Zou, J. Z., Dong, L. P., and Qin, B. P.: Preliminary studies on eutrophication and red tide problems in Bohai Bay, Hydrobiologia, 127, 27-30, 1985.

BGD

11, 7029-7054, 2014

Eutrophication

behind the

world-largest floating

macroalgal blooms

Q. Xing

Title Page

Abstract

Introduction

Conclusions

References

Tables

Figures

14

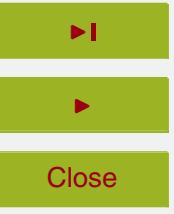

Back

Close

Full Screen / Esc

Printer-friendly Version

Interactive Discussion 
Table 1. TIN and $\mathrm{PO}_{4}-\mathrm{P}$ concentrations used for calculation of AWCPI-NP.

\begin{tabular}{lllll}
\hline Water quality level & II & III & IV & V \\
\hline TIN $\left(\mathrm{mgL}^{-1}\right)$ & 0.2 & 0.3 & 0.4 & 0.5 \\
$\mathrm{PO}_{4}-\mathrm{P}\left(\mathrm{mgL}^{-1}\right)$ & 0.015 & 0.030 & 0.030 & 0.045 \\
\hline
\end{tabular}

BGD

11, 7029-7054, 2014

Eutrophication

behind the

world-largest floating

macroalgal blooms

Q. Xing

Title Page

Abstract

Introduction

Conclusions

References

Tables

Figures

14

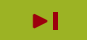

4

Back

Full Screen / Esc

Printer-friendly Version

Interactive Discussion 
Table 2. The satellite-derived annual maximum daily covering areas of floating macroalgae.

\begin{tabular}{lll}
\hline Year & Day-Month & Covering area, $\mathrm{km}^{2}$ \\
\hline 2007 & 17 Jun & 110 \\
2008 & 31 May & 1200 \\
2009 & 22 Jul & 860 \\
2010 & 9 Jul & $310^{\star}$ \\
2011 & 20 Jul & 700 \\
2012 & 21 Jun & $300^{\star}$ \\
2013 & 29 Jun & 1110 \\
\hline
\end{tabular}

* Due to the impact of clouds, the covering area is less estimated by about $50-150 \%$.

Eutrophication

behind the

world-largest floating macroalgal blooms

Q. Xing

Title Page

Abstract Introduction

Conclusions References

Tables Figures

14

4

Back

Close

Full Screen / Esc

Printer-friendly Version

Interactive Discussion 


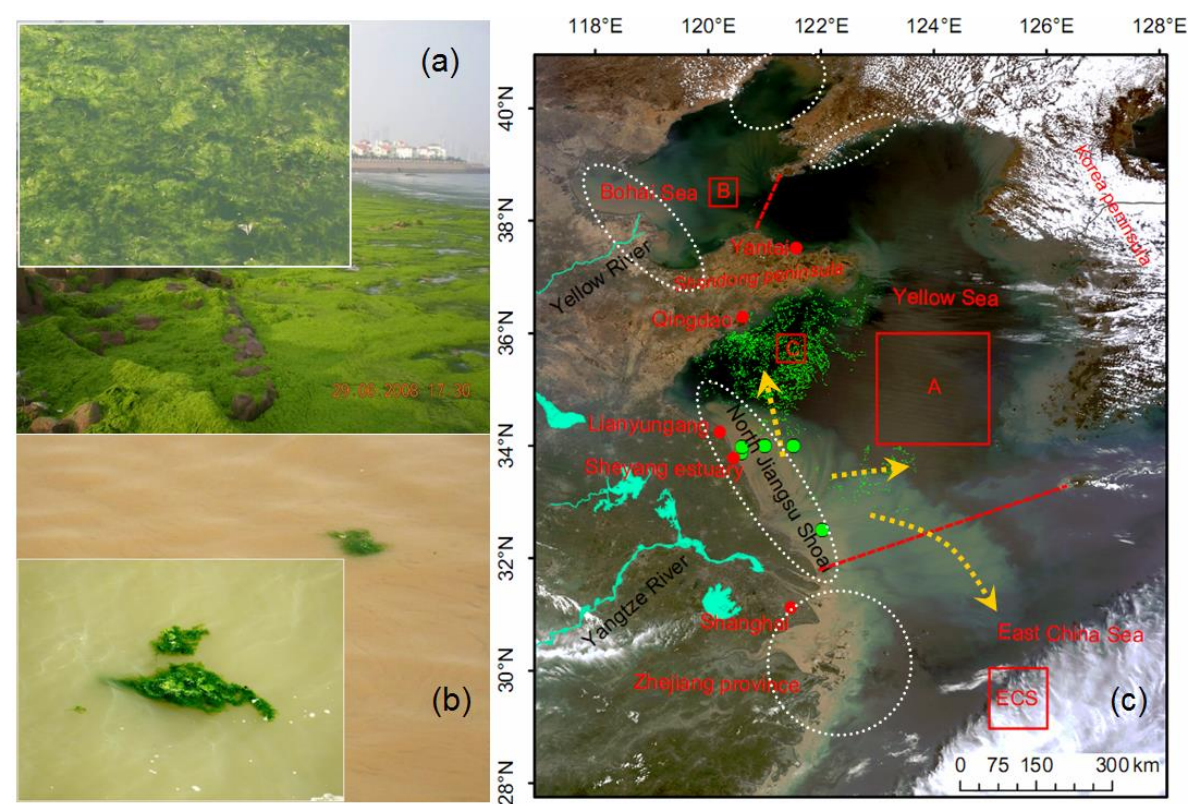

Fig. 1. In-situ photos of Ulva prolifera of green algae (a) covering the beaches in Qingdao on 29-June-2008 (photo by Qianguo Xing and Xianzheng Yuan) and (b) floating in the Northern Jiangsu Shoal (photo by Qianguo Xing and Yanju Hao). (c) Map of the spatial distribution of the green tide. Green patches are the sites of the annual maximum daily covering area of macroalgae from 2007 to 2013; green dots indicate the locations where macroalgae were validated in the cruise in the May of 2009; brown arrows show the major drifting pathways of floating macroalgae; the four red boxes show the locations where satellite-derived chlorophyll concentration was extracted; the red dash lines show the boundary of the Yellow Sea; the whitedot circles show the major polluted sites; the background image (generated by Qianguo Xing) is a true colour composite of bands 1(R), 4(G), 3(B) of MODIS acquired on 31 March 2010 (http://ladsweb.nascom.nasa.gov/).
BGD

11, 7029-7054, 2014

Eutrophication

behind the

world-largest floating macroalgal blooms

Q. Xing

Title Page
Abstract

Conclusions

Tables

14
Introduction

References

Figures

$\rightarrow 1$
Back

Close

\section{Full Screen / Esc}

Printer-friendly Version

Interactive Discussion 



Year
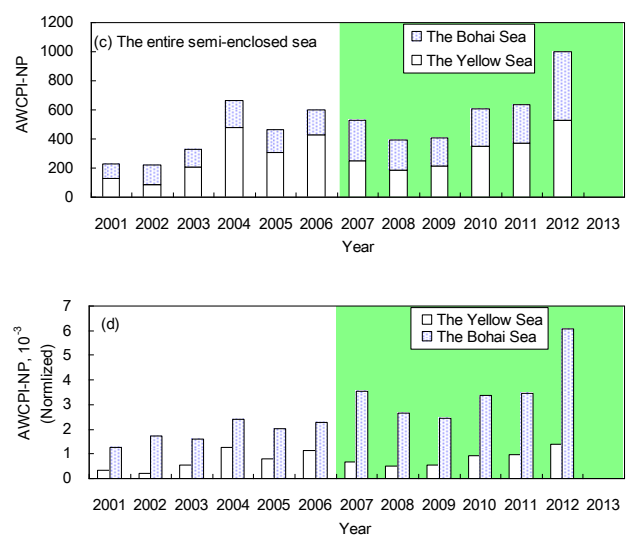

Fig. 2. (a) and (b) changes in nutrient quality levels in the Yellow Sea and the Bohai Sea, respectively, (c) the AWCPI-NP in the entire semi-enclosed sea, and (d) the AWCPI-NP normalized by the areas of the Yellow Sea $\left(380000 \mathrm{~km}^{2}\right)$ and the Bohai Sea $\left(77000 \mathrm{~km}^{2}\right)$. The green colour indicates the time span of super floating macroalgal blooms since 2007.
BGD

11, 7029-7054, 2014

Eutrophication

behind the

world-largest floating macroalgal blooms

Q. Xing

Title Page

Abstract

Introduction

Conclusions

References

Tables

Figures

14

I

4

Back

Close

\section{Full Screen / Esc}

Printer-friendly Version

Interactive Discussion 


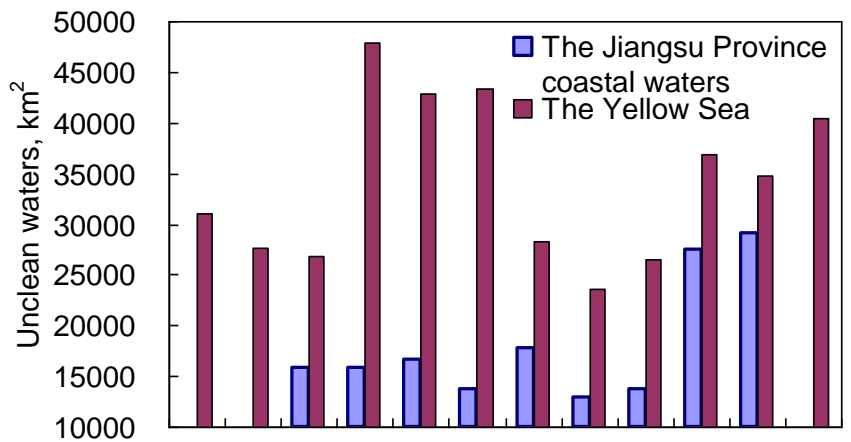

BGD

$11,7029-7054,2014$

Eutrophication

behind the

world-largest floating macroalgal blooms

Q. Xing

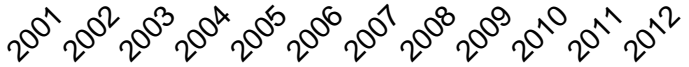

(a)

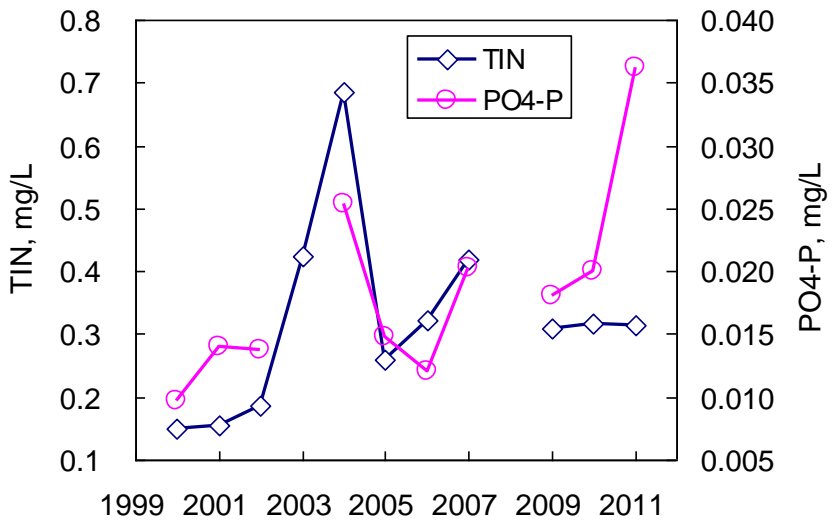

(b)

Fig. 3. Increasing trends in polluted area (a) and nutrient concentrations (b) in the Jiangsu Shoal behind the macroalgae blooms.

Title Page

Abstract Introduction

Conclusions

References

Tables

Figures

14



4

Back

Close

Full Screen / Esc

Printer-friendly Version

Interactive Discussion 


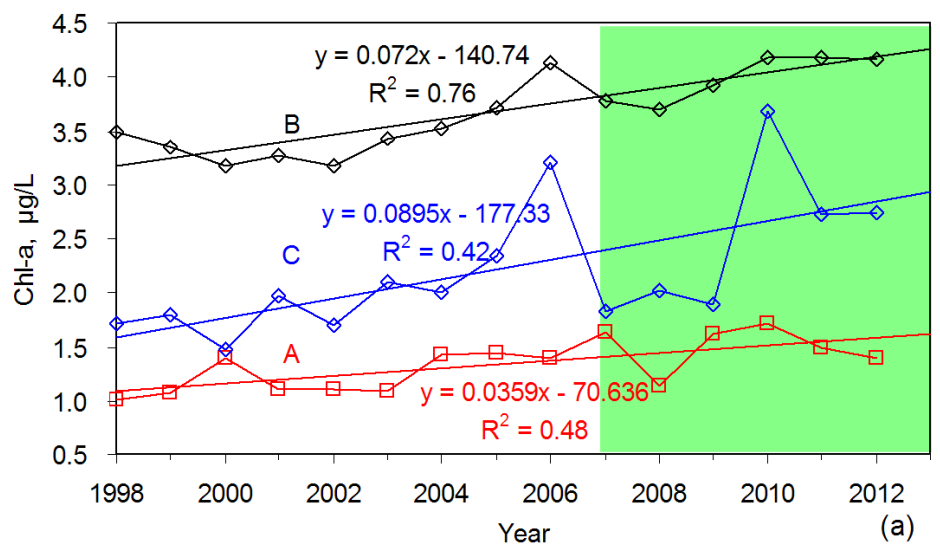

BGD

11, 7029-7054, 2014

Eutrophication

behind the

world-largest floating

macroalgal blooms

Q. Xing

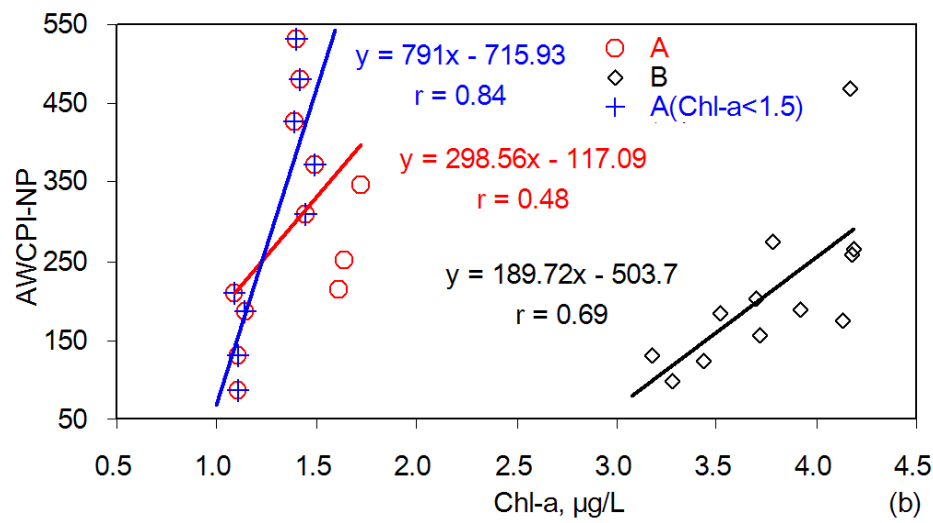

Title Page

Abstract

Introduction

Conclusions

References

Tables

Figures

14

I

4

Back

Close

Full Screen / Esc

Printer-friendly Version

Fig. 4. (a) Increases in the satellite-derived Chl a from 1998 to 2012 (the green colour indicates the time span of super macroalgal blooms), (b) relation between $\mathrm{Chl} a$ and the AWCPI-NP of the Yellow Sea (A) and the Bohai Sea (B) in 2001-2012.

Interactive Discussion 


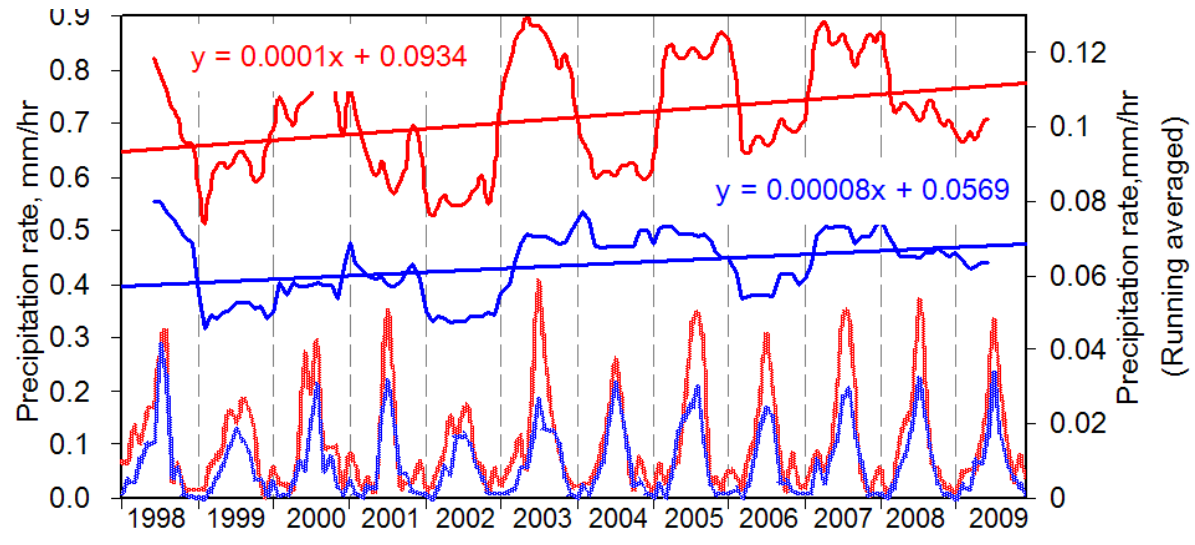

Fig. 5. Increasing trends in precipitation in the coastal regions of the Yellow Sea (red lines) and the Bohai Sea (blue lines). The solid lines show the 12-point running averaged precipitation rates.

\section{BGD}

11, 7029-7054, 2014

Eutrophication

behind the

world-largest floating macroalgal blooms

Q. Xing

Title Page

Abstract

Introduction

Conclusions

References

Tables

Figures

14

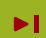

4

Back

Close

Printer-friendly Version

Interactive Discussion 


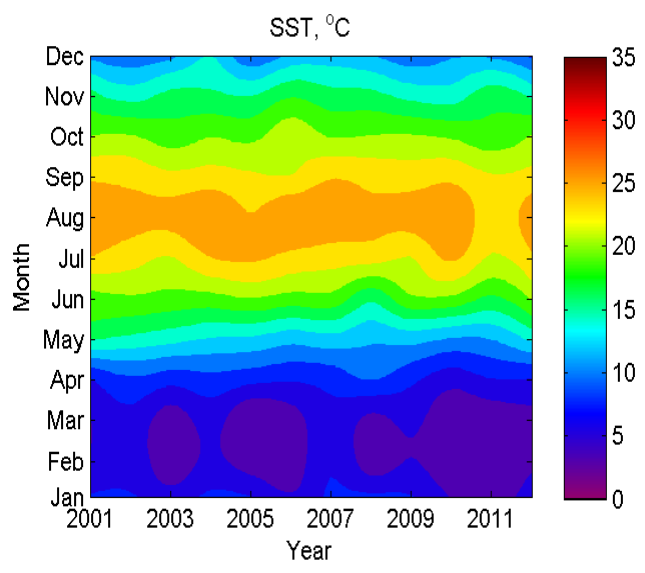

(a)

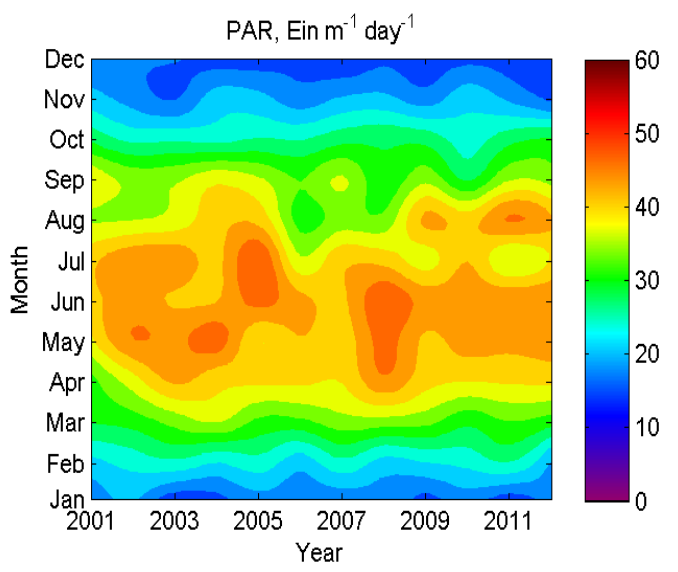

(b)

Fig. 6. Monthly SST and PAR in the period of 2001-2012 in the area with frequent occurrence of macroalgae (Box C).

Eutrophication behind the world-largest floating macroalgal blooms

Q. Xing

\section{Title Page}

\section{Abstract}

Conclusions

Tables

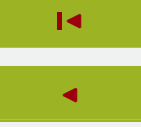

Back

Full Screen / Esc

Printer-friendly Version 